Expert Rev Respir Med. 2018 September ; 12(9): 755-767. doi:10.1080/17476348.2018.1506331.

\title{
The effect of obesity on lung function
}

\author{
Ubong Peters and Anne E. Dixon* \\ University of Vermont Larner College of Medicine, Burlington, Vermont.
}

\begin{abstract}
Introduction: There is a major epidemic of obesity, and many obese patients suffer with respiratory symptoms and disease. The overall impact of obesity on lung function is multifactorial, related to mechanical and inflammatory aspects of obesity.
\end{abstract}

Areas Covered: Obesity causes substantial changes to the mechanics of the lungs and chest wall, these mechanical changes cause asthma and asthma-like symptoms such as dyspnea, wheeze and airway hyperresponsiveness. Excess adiposity is also associated with increased production of inflammatory cytokines and immune cells that may also lead to disease. This article reviews the literature addressing the relationship between obesity and lung function, and studies addressing how the mechanical and inflammatory effects of obesity might lead to changes in lung mechanics and pulmonary function in obese adults and children.

Expert Commentary: Obesity has significant effects on respiratory function, which contribute significantly to the burden of respiratory disease. These mechanical effects are not readily quantified with conventional pulmonary function testing and measurement of BMI. Changes in mediators produced by adipose tissue likely also contribute to altered lung function, though as of yet this is poorly understood.

\section{Keywords}

Airway hyperreactivity; Adipose tissue; Metabolism; Pulmonary function

\section{Introduction}

The worldwide prevalence of obesity has been on the rise in the past three decades, resulting in an increase in the prevalence, morbidity and clinical presentation of many respiratory diseases. Obesity is an important risk factor and disease modifier for asthma, obstructive sleep apnea, obesity hypoventilation syndrome (OHS), and pulmonary hypertension. The condition affects outcomes in acute respiratory distress syndrome (ARDS) and chronic obstructive pulmonary disease (COPD). Obesity increases susceptibility to respiratory

\footnotetext{
"Corresponding author: Anne E. Dixon, Division of Pulmonary and Critical Care Medicine, University of Vermont Larner College of Medicine, Given D209, 89 Beaumont Avenue, Burlington, VT 05305, Office: (802) 656-3590. Fax: (802) 656-8926, anne.dixon@uvmhealth.org.

Declaration of interest

The authors have no other relevant affiliations or financial involvement with any organization or entity with a financial interest in or financial conflict with the subject matter or materials discussed in the manuscript apart from those disclosed.

Reviewer disclosures

Peer reviewers on this manuscript have no relevant financial or other relationships to disclose.
} 
infections, and hospitalization rates are higher in obese patients with respiratory disease, as compared to healthy weight subjects. This article presents an overview of the effects of obesity on normal physiology and function of the lung, and discusses how this engenders pathophysiology.

\section{Epidemiology of obesity and obesity-related lung disease}

The prevalence of obesity has reached epidemic proportions, especially in developed countries. In the United States, approximately $40 \%$ of the adult population is obese [1]. Children are not spared by the obesity epidemic - currently, about $19 \%$ of US children are obese [1]. This sudden rise in the prevalence of obesity has affected the epidemiology of many pulmonary diseases.

Asthma is one of the best-characterized diseases related to obesity. A meta-analysis involving over 300,000 adults found obesity and asthma were related, and the risk of asthma increased with increasing BMI [2]: the odds ratio for incident asthma in the overweight group was 1.5 (95\% CI; 1.2-1.6) compared to normal weight subjects, whereas the odds ratio in the obese group was 1.9 (95\% CI; $1.4-2.6)$. This implies that approximately 250,000 new cases of asthma per year in the United States are related to obesity. The prevalence of obesity among patients with COPD is also higher than among those without COPD [3].

\section{Body mass index and patterns of regional fat distribution}

Body mass index (BMI) is used to classify obesity. It is calculated as the ratio of weight in kilograms to the square of height in meters, expressed in units of $\mathrm{kg} / \mathrm{m}^{2}$. In adults, overweight is defined as a BMI greater than $25 \mathrm{~kg} / \mathrm{m}^{2}$ and obesity greater than $30 \mathrm{~kg} / \mathrm{m}^{2}$. In children, the classification system is based on age- and gender-matched normative data for BMI: overweight is defined as BMI above the $85^{\text {th }}$ percentile compared with their age- and gender-matched counterparts, BMI above the $95^{\text {th }}$ percentile is considered obese. BMI is a very simple and convenient method to classify the severity of obesity. Its main weaknesses are limited specificity, since it does not distinguish between fat mass and lean (muscle) mass, and its inability to account for the pattern of regional fat distribution.

There are two main regional fat distribution patterns: central and peripheral (Figure 1). Central (abdominal or android) obesity is characterized by increased deposition of fat in the thorax, abdomen and visceral organs, and an apple-like body shape. Peripheral (gynoid) obesity is characterized by deposition of fat in the hips, thighs and limbs, and in subcutaneous tissue, and a pear like body shape. This distinction is important. Android obesity is likely to have a more direct effect on pulmonary mechanics than gynoid obesity [4]. Android obesity also has a greater impact on metabolic inflammation. Obesity is a chronic state of low-grade inflammation, which differs between subtypes of obesity. Gynoid obesity manifests as increased subcutaneous fat, whereas android obesity manifests as increased visceral fat. Visceral fat is a more metabolically active than subcutaneous fat. Indeed, increased visceral fat mass is linked to the metabolic syndrome [5], and the metabolic syndrome has been linked to asthma and impaired lung function in both adolescents and adults. 


\section{The mechanics of the lungs and chest wall in obesity and respiratory compliance}

The mechanical properties of the lungs and chest wall are altered significantly in obesity, largely due to fat deposits in the mediastinum and the abdominal cavities. These alterations reduce the compliance of the lungs $[6,7,8]$, chest wall and entire respiratory system $[8,9]$, and likely contribute to the respiratory symptoms of obesity such as wheeze [10], dyspnea [11], and orthopnea [12]. The reduction in respiratory system compliance (increased stiffness) also alters the breathing pattern. Air typically flows into the lungs along the negative pressure gradient within the pleural space. However, intra-abdominal and pleural pressures are increased slightly in obesity, because the downward movement of the diaphragm and the outward movement of the chest wall are restricted when fat accumulates within the thoracic and abdominal cavities [13, 14]. This alters the breathing pattern resulting in a substantial reduction in both the expiratory reserve volume (ERV) and the resting volume of the lung, known as the functional residual capacity (FRC). The reduction in FRC is proportional to the severity of obesity - overweight, mildly obese and severely obese subjects without asthma demonstrate reductions in FRC of up to 10\%, 22\% and 33\%, respectively [15]. Tidal volume is also slightly lower in obese subjects [16]; however, a slight increase in the mean respiratory rate compensates for the shallow breathing pattern, such that the overall minute ventilation is increased significantly $[17,18]$.

The mechanisms behind the reduction in respiratory system compliance in obesity have not been clearly elucidated - it is not yet known whether the reduction in respiratory system compliance is largely driven by a reduction in the compliance of either the lungs or chest wall, or a combination of the two (Table 1). Studies have variably reported reductions in the compliance of both the lungs and chest wall [6], reduction in lung compliance with normal chest wall compliance, and normal lung compliance with reduced chest wall compliance. Despite the conflicting findings, several studies have reported that chest wall and lung compliance are both reduced in obesity $[6,7,8,19]$. It is very likely that the reduction in lung volumes induced by the obese state is a major contributor to the decreased compliance of the lungs, whether tissue mechanics are also affected is not clear.

\section{The effects of childhood obesity on lung function and airway dysanapsis}

Obesity has a significant effect on lung function in children. Childhood obesity is associated with a supra-normal or higher $\mathrm{FEV}_{1}$ and FVC, and a lower FEV1/FVC ratio [20, 21], even after adjusting for height [22]. This unexpected increase in $\mathrm{FEV}_{1}$ and $\mathrm{FVC}$ in obese children is due to airway dysanapsis, an incongruence between growth of the lung tissue and airway caliber [23]. The lung grows at an accelerated pace in children with obesity resulting in airway dysanapsis, measured as an FVC increased disproportionately compared with $\mathrm{FEV}_{1}$. Other lung volumes such as TLC, RV and FRC are reduced in children with obesity [21]. 


\section{Effect of obesity on lung volumes and expiratory flows}

Although obesity significantly reduces functional residual capacity (FRC) and expiratory reserve volume (ERV) [15, 24, 25], it has very little effect on residual volume (RV) and total lung capacity (TLC). Several studies have demonstrated small reductions in TLC with increasing BMI, but TLC is usually well-preserved even in patients with severe obesity [4, $15,26,27] . \mathrm{RV}$ is typically within the normal range in people with obesity $[4,15,26]$, and the RV-to-TLC ratio, an indicator of gas trapping, is also normal or slightly increased [15].

Measurements of static pulmonary volumes combined with measurements of transpulmonary and transdiaphragmatic pressures have provided deeper insights into the effects of obesity on lung mechanics and subsequent lung volumes. A landmark study on the effect of obesity on lung volumes measured in the seated position demonstrated that esophageal and gastric pressure at FRC were significantly elevated in obese subjects as compared to their healthy counterparts who were matched for age, gender and height [28]. Similar results were recorded in the supine position, and BMI correlated with gastric and esophageal pressures.

Other dynamic measures of pulmonary function such as $\mathrm{FEV}_{1}$ and FVC are slightly reduced in the presence of obesity $[10,11,29]$, but $\mathrm{FEV}_{1} / \mathrm{FVC}$ ratio is usually unaffected $[10,11,30]$ unless BMI is greater than $62 \mathrm{~kg} / \mathrm{m}^{2}$ [31]. When ERV decreases, while vital capacity (VC) remains normal, inspiratory capacity (IC) will be increased [32]. Rasslan and coworkers showed that inspiratory capacity was higher in obese individuals than in non-obese individuals [33], though other investigators found no significant differences [29, 34].

Body fat distribution pattern has a stronger association with pulmonary function than weight or BMI [35, 36]. A large population-based study of 121,965 individuals found increased abdominal obesity was a risk factor for reduced $\mathrm{FEV}_{1} / \mathrm{FVC}$ [35], abdominal obesity predicted $\mathrm{FEV}_{1}$ and $\mathrm{FVC}$ independent of BMI [35]. Taken together, these findings suggest that obesity does not really affect the ability of patients to fully inflate or deflate their lungs, but significantly reduces resting lung volumes. The mechanical effects of obesity on lung mechanics and function may not be fully reflected in these indices of pulmonary function routinely measured in the clinic, as obesity is likely to most significantly affect airway narrowing and closure as discussed below.

\section{The effect of obesity on airway narrowing and airway closure}

The mechanical effects of obesity produce airway narrowing and closure, and increased respiratory system resistance. Compared to healthy weight controls, airway narrowing in obesity correlates with airway closure and airway hyperresponsiveness (AHR) [37]. Airway narrowing and closure lead to gas trapping and ventilation inhomogeneity [38]. While gas trapping and airway closure can be inferred from an elevated RV/TLC ratio [39], a recently developed method to assess airway closure is oscillometric evaluation of respiratory system impedance. In a comparative study of lung mechanics in obese versus non-obese people with asthma, Salome et al found that obesity does not alter methacholine responsiveness measured by spirometry but significantly reduces respiratory system reactance and increases 
respiratory system resistance (Rrs) [32]. Methacholine-induced reduction in respiratory system reactance was greater among obese non-asthmatics compared to their non-obese counterparts suggesting that excess adiposity could promote peripheral airway closure. Similar findings have been observed in other studies [40, 41]. This suggests that measuring respiratory system impedance may be a more sensitive measure of lung dysfunction related to obesity than spirometry.

Other indirect markers of airway closure such as RV and closing capacity are usually within normal limits in obesity [26, 42]. On the other hand, airway closure can occur during resting breathing in the obese as a result of FRC being depressed to levels at or below closing capacity [42, 43, 44], presumably due to mechanical compression of the lungs [15], which results in a reduction in forces of mechanical interdependence between the airways and parenchyma $[6,45]$. This may be reflected in obese asthmatics as a slight reduction in $\mathrm{FEV}_{1}$ [10]. Increased abdominal obesity has been linked to increased airway closure in the paradiaphragmatic lung regions and this impaired cranio-caudal distribution of inspired gas (see below), especially in the supine position [46].

The mechanisms increasing respiratory system resistance and decreasing respiratory system reactance in obesity $[29,32]$ are not completely understood, but it is thought that the reduction in FRC attenuates the forces of interdependence between the airway and parenchyma and reduces airway caliber $[6,45]$. Airway caliber is sensitive to airwayparenchymal tethering forces and breathing at a reduced FRC, due to mechanical compression of the lungs, likely plays a dominant role in increasing Rrs in obese subjects $[29,47]$. In addition, breathing at low lung volumes also increases airway hyperresponsiveness (AHR) [48] (see below). Van Noord et al, Torchio et al, and Navajas et al conducted studies involving rib cage strapping [49,50] and supine positioning [51] to mimic reduced lung volumes from obesity-induced mechanical compression of the respiratory system. These experiments showed increased respiratory system resistance, and increased AHR in one study [50], and that reduction in the operating volume of the lung in obesity-FRC-could potentially amplify symptoms and manifestations related to airway narrowing or airway closure, such as AHR [52], dyspnea [11], and wheeze [10].

The other important clinical implication of reduced FRC affecting pulmonary function, is that measures to assess lung function based on taking deep tidal breaths likely obliterate this effect. Conventional spirometry likely under-estimates the impact of obesity on the normal breathing pattern in obesity. Measures of lung function that can be performed during normal tidal breathing - such as oscillometry - likely provide more valuable information about the true effect of obesity on the patient's lung function.

The effects of obesity on airway narrowing and airway closure could have other important implications for lung disease. Airway narrowing and closure increase ventilation inhomogeneity and gas trapping, respectively [38]. This could impede the delivery of inhaled medications to the small airways and contribute to the resistance to inhaled therapies often observed in obese patients with asthma [53, 54, 55, 56]. Increased airway closure could also lead to more severe exacerbations of obstructive lung disease [57] with concomitantly increased hypoxia and arterial oxygen desaturation $[42,58]$, and dyspnea 
[59]. In fact, obese patients with asthma have a four- to six-fold risk of hospitalization for an asthma exacerbation compared with lean asthmatics [60].

\section{Obesity and airway hyperresponsiveness}

Many large studies report positive associations between BMI and AHR, but this is not a uniform finding [61]. The only prospective longitudinal cohort study that investigated the relationship between obesity and AHR in more than 7,000 adults found that the risk for AHR increases as BMI increases [52]; weight gain was a risk factor for developing AHR, even when controlling for the effects of age, smoking, serum IgE and baseline $\mathrm{FEV}_{1}$.

Three large cross-sectional epidemiologic studies in China (7,109 participants [62]), Europe (11,277 participants [63]) and the United States (1,725 participants [64]) found AHR or symptomatic AHR was more prevalent in obese adults compared to lean subjects. In contrast, several smaller studies failed to find a consistent relationship between AHR and obesity $[10,65]$. This inconsistency may be explained by several factors such as small sample size, the outcome indicator used (respiratory system resistance, reactance, $\mathrm{FEV}_{1}$, or maximum expiratory flow at $60 \%$ of TLC), atopic status, severity of obesity in the participants and differing eligibility criteria such as enrolling only non-asthmatic obese subjects. Findings might be more consistent if the various studies used more similar eligibility criteria and outcome measures.

One hypothesis for the increased AHR in obesity is that breathing at low FRC, with a rapid breathing pattern and a reduced tidal volume, could affect the contractility of airway smooth muscle (ASM). Smooth muscle contractility is usually modulated by stretching during regular tidal breathing and deep inspirations [66]. Breathing at reduced tidal volumes in obesity may have multiple effects on ASM. The load applied to the ASM is reduced, increasing shortening velocity, and allowing length adaptation (mechanical plasticity) -ASM adapts to a shorter length by rearranging its contractile apparatus to maintain force generating capacity $[67,68,69]$, generating more force at a shorter length. Another potential mechanism is that reduced tidal volume breathing might not disrupt actin-myosin crossbridges, allowing ASM to stiffen. Tissue strip experiments showed that large tidal oscillations and large stretches reduce ASM force, lengthen ASM and soften (fluidize) the muscle $[66,70,71,72]$. This mechanism could explain the maintenance of airway dilation in healthy subjects even during a methacholine challenge [73], and how smaller tidal stretching in obesity might impair this effect. The in-vivo relevance of this is not clear, however, as very large stretches are required in intact airways, and the effect is less substantial than in tissue strip experiments [74]. Nevertheless, it is possible that reduced ASM length with reduced tidal stretching at FRC in obesity could reduce disruption of actin-myosin crossbridges thus leading to AHR. Another implication would be that measuring AHR with spirometry - which involves taking in a breath to total lung capacity - may obliterate AHR related to breathing at FRC. Conventional measures of AHR likely underestimate AHR in obesity. 


\section{Bronchial reversibility in obese patients with or without asthma}

There are few studies of the effect of obesity on bronchodilator (BD) responsiveness. These studies, which relied on spirometry to investigate BD responsiveness in obesity, showed conflicting results. The first of these studies conducted by Castro-Rodriguez et al found that girls who became overweight or obese between the ages of 6 and 11 were more likely to demonstrate bronchial reversibility than girls who did not become overweight or obese [75]. However, Tantisira et al later reported that BD responsiveness decreased with increasing body mass index (BMI) in obese children [20]. A third study, in adults, failed to establish a relationship between obesity and reversible airway obstruction [76]. Using oscillometry, we found that responsiveness to short-acting $\beta_{2}$-adrenergic agonists is severely reduced in healthy obese patients awaiting bariatric surgery, but this was restored to the normal range following modest weight loss [77]. These conflicting findings suggest that some subtle changes in lung mechanics and function induced by obesity are more readily detectable with oscillometry than with spirometry. There are no published studies of bronchial reversibility in obese adults with asthma using oscillometry.

\section{Effect of obesity on regional ventilation and perfusion distribution in the lung}

The normal distribution of ventilation is altered in obesity, resulting in ventilation-perfusion mismatch. Holley et al demonstrated that, in upright-seated obese patients with severely reduced ERV, ventilation is preferentially distributed to the poorly perfused upper lung zones [78]. Perfusion distribution is substantially greater in the lower lung zones because of the effects of gravity; however, this zone is usually not well-ventilated if resting breathing (FRC) is depressed to levels that approach RV, as is commonly observed in obesity [15, 24, 25]. These changes result in an abnormal regional ventilation-perfusion relationship and a reduced arterial oxygen tension during normal tidal breathing. Severely obese subjects who were otherwise healthy have reduced arterial $\mathrm{PO}_{2}$ and increased alveolar-arterial $\mathrm{PO}_{2}$ difference [79], attributable to mild to moderate shunt and a VA/Q imbalance induced by the obese state. Surprisingly, these changes are not fully reflected in measurements of the lung's diffusing capacity for carbon monoxide (DLCO). Studies on the effect of obesity on DLCO have provided conflicting results: some investigators report that DLCO is decreased, likely due to a reduced alveolar volume or structural changes to the interstitium caused by increased lipid deposition [80]; others have reported that DLCO is normal [8]; yet others have suggested that DLCO is increased in severely obese patients, likely due to increased pulmonary blood volume [47].

\section{Effect of weight loss on lung mechanics and function}

If obesity is the main driver for changes in lung mechanics and function, then weight loss might reverse these changes. Several studies have investigated whether obesity induces a permanent pathological level of remodeling in the lung, or whether weight loss can restore respiratory physiology. Many investigators have reported some improvement in peak expired flow and spirometric indices after weight loss in obese patients with and without asthma [81, 
82, 83]. Significant increases in lung volumes, notably TLC, FRC and ERV, have also been reported (Figure 2) [58, 77, 84].

Other studies have investigated the effects of weight loss on airway reactivity [40, 82, 85]. Aaron et al found a trend towards reduced AHR with weight loss following an intense dietinduced weight reduction program in obese asthmatics and controls $(p=0.23)$ [82]. We reported that a $27 \%$ weight loss in asthmatic women who underwent bariatric surgery was associated with a significant reduction in AHR $(p=0.03)$ [85], though atopic (high serum IgE) participants did not demonstrate change in AHR with weight loss, whereas weight loss resulted in significant reductions in AHR in non-atopic subjects. Subjects in the atopic group reported asthma since childhood, and their serum $\operatorname{IgE}$ concentrations were unchanged following weight loss suggesting allergic disease. The non-atopic group had a diagnosis of asthma, but without allergy suggesting another mechanism for their asthma symptoms, likely mechanical compression of the lung and metabolic disarray related to obesity [41].

These results gave rise to the notion of at least two distinct clinical phenotypes of asthma in obesity - those with early onset asthma and high serum IgE $\left(\mathrm{T}_{\mathrm{H}}\right.$ 2-high) and those with late onset asthma and low serum $\operatorname{IgE}\left(\mathrm{T}_{\mathrm{H}} 2\right.$-low). Chapman et al further investigated these findings by assessing the effect of weight loss on sensitivity to small airway closure during methacholine challenge in the two obese asthmatic groups (allergic and non-allergic) compared to obese controls [40]. They found significantly higher airway responsiveness to methacholine in the two obese asthmatic groups compared to the control group. Sensitivity to airway closure improved only in the $\mathrm{T}_{\mathrm{H}}$ 2-low asthmatics. Also, the reduction in closing index caused by weight loss was similar in obese patients with early- versus late-onset asthma [40]. This suggests that it is obesity per se, and not the duration of asthma, that increases the risk of airway closure.

These weight loss studies suggest that obesity exerts a strong mechanical effect on the respiratory system, and depending on the asthma phenotype (atopic versus non-atopic), this could potentially increase the risk of AHR. The mechanical effects of obesity on the respiratory system together with the metabolic effects of excess adiposity could indirectly contribute to AHR likely through mechanisms such as airway narrowing and airway remodeling.

\section{Adipose tissue inflammation and lung function in obesity}

Obesity significantly affects the immune cells in adipose tissue. Adipose tissue macrophages are significantly increased (Figure 3). Weisberg et al isolated subcutaneous adipose tissue of obese individuals and determined that adipose tissue macrophages accounted for up to 50\% of the cells in the tissue when stained for the macrophage antigen-CD68 [86]. Sideleva et al reported increased infiltration of subcutaneous adipose tissue and visceral adipose tissue by macrophages in obese individuals with asthma, though this did not correlate with measures of inflammation in the lung [87]. Peryalill et al reported these macrophages were predominantly of a pro-inflammatory phenotype [88]. Increased adipose tissue mass is also associated with increased mast cell propagation. Mast cells are key mediators of allergy, and adipose tissue is an important source of mast cell progenitor cells [89]. Indeed, compared to 
lean individuals, the burden of mast cells is increased in obese humans and mice [90] suggesting that obesity-induced mast cell proliferation might be another potential mechanism for airway disease in obesity.

\section{Adipokines and systemic inflammation in obesity}

Adipose tissue is an important endocrine organ that secretes adipocyte-derived factors known as adipokines, which might affect airway function. Adipokines are energy-regulating proteins synthesized and secreted by adipose tissue. Adipokines are differentially expressed in the adipose tissue of obese subjects compared with lean subjects, and in obese patients with asthma compared to those without asthma. Expression of adiponectin-the most abundant anti-inflammatory adipokine in the adipose tissue-is markedly reduced; expression of leptin-a pro-inflammatory adipokine - is increased, in obese patients with asthma [87].

Leptin is an anorexigenic hormone, which also increases metabolism and regulates immune function (Figure 3). Leptin plays an important role in the regulation of ventilatory drive [91, 92], and is involved in surfactant production and neonatal lung development [93, 94]. Given these functions, leptin could certainly be involved in the pathogenesis of airway disease. Visceral fat leptin expression has been found to strongly correlate with AHR [87] and a high serum leptin concentration is inversely associated with reduced lung function in obese American women of African descent [95]. Both high BMI and high serum leptin concentration are strongly associated with asthma in adults [96], the association between BMI and asthma was unchanged even after controlling for leptin, suggesting that the relationship between obesity and asthma is not mediated by leptin alone. In contrast, other studies found no significant difference in the serum concentrations of leptin in obese asthmatics and obese non-asthmatic adults [87]. These contrasting results may be related to different populations, and different phenotypes of asthma.

Other inflammatory mediators that are increased in obesity include tumor necrosis factor alpha (TNF-a) [97, 98], interleukin (IL-) 8 and IL-6 [99], high-sensitivity C-reactive protein (hs-CRP) and monocyte chemoattractant protein-1 (MCP-1) [100]. In addition, the level of circulating leukocytes in the blood of obese subjects is increased compared to lean individuals [101]. The role of these other cytokines in obese asthma is not well-understood.

\section{Airway inflammation and lung function in obesity}

Several studies have investigated whether the increased levels of pro-inflammatory adipokines and cytokines observed in the systemic circulation of obese patients are linked to increased airway inflammation. Sputum eosinophils tend to decrease with increasing BMI [102], though airway wall eosinophils are increased [103]. Some studies have shown an increase in sputum neutrophils with increasing BMI [104]. The effect of obesity on airway inflammation has also been assessed in bronchoalveolar lavage (BAL) fluid of obese humans and mice. Elevated levels of pro-inflammatory mediators such as IL-6, MCP-1 and neutrophils were observed in the BAL fluid of $C p e^{f a t}$ mice compared to lean controls following ozone exposure but not air exposure [105]. In fact, exogenous administration of leptin to lean control mice prior to ozone exposure augments ozone-induced increases in 
IL-6 in BAL fluid [106]. In human subjects, however, there is no concrete evidence of elevated airway inflammation in BAL fluid of patients with obesity. Similar cell counts of macrophages, neutrophils, lymphocytes and eosinophils were found in BAL fluid of obese asthmatics and non-asthmatics [85]. There is mounting evidence that the adipose tissue is the site and source of chronic inflammation that is associated with airway disease and abnormal lung function, but not necessarily airway inflammation. The effect of these adipose tissue derived factors on structural cells of the airway is not known.

\section{Effect of obesity on diseases of the heart and lungs}

The respiratory system is constantly under stress as it works to meet the ventilatory demands of the body. Work of breathing is increased in diseases such as ARDS, pneumonia and heart failure, and the physiological response of the lungs to the increased ventilatory demands is complicated by the obese state. Currently, few studies have assessed how obesity specifically impacts pulmonary function during acute episodes of these conditions [107, 108]. However, it has been clearly shown that obesity is a risk factor for heart disease [109], and obese patients have an increased susceptibility to influenza and bacterial pneumonia $[110,111]$ and suffer worse outcomes from these conditions. Obese patients also have an increased risk of developing ARDS but paradoxically, they have the lowest risk of mortality from the condition [112]. The likely mechanisms that underlie these effects are poorly understood, but it is thought that obesity-induced imbalances in adipokine levels could impair pulmonary vascular endothelial function and prime the lung for injury [113]. Defects in neutrophil chemotaxis and survival are also thought to play a role [114].

\section{Metabolic changes in obesity and its effect on lung function}

The metabolic dysregulation that accompany the obese state has direct consequences on pulmonary function and lung disease. Insulin resistance and dyslipidemia can contribute to epithelial damage and ASM proliferation [115, 116], consequently leading to AHR. Indeed, metabolic syndrome is associated with poor lung function in obese and non-obese adults and children with and without asthma [117, 118, 119]. Diabetes is also associated with poor lung function and pulmonary hypertension in both mice and men [120, 121, 122]. Poorly controlled diabetes has been implicated in the loss of lung function in patients with cystic fibrosis [123]. Interestingly, metabolic dysregulation in obesity is often linked to a restrictive pattern of lung disease [124]. Abdominal obesity and metabolic syndrome, but not diabetes, were independently associated with restrictive lung disease among older patients with diabetes and metabolic syndrome $[125,126]$. Patients with restrictive lung disease demonstrated higher levels of insulin resistance than healthy subjects or patients with obstructive lung disease.

\section{Effect of aging on the relationship between obesity and pulmonary function}

Generally, lung function gradually declines with age, even among healthy individuals [127]. The maximal inspiratory pressure, which is a measure of respiratory muscle strength has been shown to decrease by about 0.8 to $2.7 \mathrm{~cm} \mathrm{H}_{2} \mathrm{O}$ per year between the ages of 65 to 85 , 
with larger declines observed in men [128]. Since obesity significantly affects many diseases of the lung, it seems plausible to assume that it might also modulate the relationship between aging and rate of lung function decline. However, there is no clear evidence that obesity per se increases or reduces the rate of lung function decline with age, but there is evidence that it is paradoxically protective of lung function in patients with COPD [129]. Indeed, respiratory-related deaths are reduced among obese patients with severe COPD [129]. Lazarus et al [30] also reported that BMI was negatively correlated with vital capacity (VC) in subjects aged 40 to 69 years; however, after adjusting for BMI, the authors found a similar negative association between $\mathrm{VC}$ and ratio of abdominal girth to hip breath in subjects aged 50-59. The mechanism modulating the effect of aging on lung function in obesity is still the subject of intense scientific debate, but these studies suggest that BMI and pattern of regional fat distribution may have independent effects on lung function that vary with age. In fact, age-related changes to the structure of the rib cage could lead to reductions in the total compliance of the respiratory system. One study which assessed the effect of age on the relationship between chest wall compliance and lung compliance in a group of healthy males aged 24-78 years found reduced chest wall compliance among older subjects, despite measuring similar lung compliances in both young and old [130].

\section{Relationship between obesity and risk of pulmonary complication after surgery}

Although it seems plausible that obesity is an additional risk factor for post-operative complications, very few studies have examined this in the context of respiratory complications. Many factors determine the risk of complications after surgery. These include: the type of surgery (chest or abdominal incision), duration of surgery, and the patient's medical history. Post-operative respiratory complications in obese patients may be related to reduced FRC, reduced TLC, reduced VC, increased risks of aspiration pneumonitis and ventilator-assisted pneumonia, and pulmonary embolism. To-date, there is no concrete evidence that high BMI is a major risk factor for respiratory complications after surgery in otherwise healthy obese patients. However, in patients undergoing pneumonectomy for lung cancer, the risk of respiratory complications was 5.3 times higher in patients with BMI $>25 \mathrm{~kg} / \mathrm{m}^{2}$ as compared to patients with BMI $<25 \mathrm{~kg} / \mathrm{m}^{2}$ [131]. Similar studies are needed to understand how high BMI might impact respiratory complications in other obese populations. One study reported that atelectasis persists for more than 24 hours after surgery in severely obese patients, whereas complete resorption of atelectasis was observed in non-obese patients during that period [132]. Post-operative pulmonary function may be improved by applying continuous positive airway pressure or positive end-expiratory pressure during surgery to prevent atelectasis and improve overall ventilation distribution to lung airspaces. Ventilation can also be optimized by placing patients in the reverse Trendelenburg position [133]. Extra precaution must be taken when providing post-operative care to patients with obesity. 


\section{Conclusions}

The epidemic of obesity has increased the prevalence and morbidity, and altered the clinical presentation of many respiratory diseases. Accumulation of fat in the mediastinum and the abdominal cavities significantly alters the mechanical properties of the lungs and chest wall, and this contributes to changes in the normal physiology and function of the lungs. Obesity is an important risk factor and disease modifier of many respiratory conditions. Some of the respiratory symptoms commonly associated with obesity include wheeze, dyspnea, and orthopnea. Airway hyperresponsiveness is also increased as BMI increases. Conventional measures of lung function are likely not sensitive or specific for assessing lung function abnormalities related to the reduced operating volume of the respiratory system in obesity. The mechanisms behind these obesity-induced changes in lung function are complex, involving mechanical changes, and effects of adipokines and inflammatory cytokines from adipose tissue.

\section{Expert Commentary}

There is a major epidemic of obesity, and this is changing the nature of lung diseases commonly encountered in medical practice. Obesity and diseases such as asthma are complex diseases with many different phenotypes: careful phenotyping of both the type of obesity and the type of lung disease are required to understand the effects of obesity on diseases such as asthma.

One important example of this is illustrated by the fact that Impairment in lung function is more closely related to waist circumference rather than BMI. BMI is likely a poor measure of the effects of obesity on the lung. Waist circumference is a measure of both mechanical impingement and metabolic inflammation, and so measuring waist circumference provides valuable information when assessing the degree of mechanical lung function impairment related to obesity, and provides at least one marker of metabolic derangement related to obesity.

Measuring the effects of obesity on respiratory system function is under-estimated by standard pulmonary function tests used in the clinic. Respiratory system mechanics are dramatically altered by obesity, due in large part to breathing at lower lung volumes, and yet the standard testing used to measure lung function in the clinic consists of forced maneuvers and deep breaths which obliterate changes related to breathing at low functional residual capacity. Studies using more advanced techniques to measure lung function during normal quiet breathing, such as oscillometry, are likely to more clearly elucidate effects of obesity on the respiratory system.

Another important factor, not measured either clinically or in most studies, is altered patterns of ventilation within the lung. In severe obesity, ventilation is pre-dominantly to the upper lung zones, rather than the lower lung zones. This upper lobe predominant ventilatory pattern likely produces significant ventilation-perfusion abnormalities, and contributes to respiratory compromise in severely obese patients. 
There is currently great interest in understanding how obesity alters inflammatory pathways and immune function in the lung, as obesity is considered to be an inflammatory disease. However, studies in humans in many cases do not show enhanced inflammation in the airway, and so studies designed to understand how adipokines might affect structural cells in the lung to produce altered lung function are needed.

\section{Five-Year View}

In the next 5 years, we anticipate studies phenotyping both obesity and airway disease will allow insights into the mechanical and immunological effects of obesity on lung function in diseases such as asthma and COPD. This will require more sophisticated measures of adiposity than BMI, measures incorporating assessments of metabolic dysfunction and regional fat distribution. We anticipate that the use of physiologic measurements during normal tidal breathing which also assess the lung periphery, such as the forced oscillation technique and single and multi-breath nitrogen wash-out tests, will allow a better appreciation for how obesity affects lung mechanics in health and disease. We also anticipate studies that will show how adipokines and metabolic factors affect structural cells in the lungs, this will add to the literature that has currently focused on the effects of these factors on immune cells.

\section{Acknowledgments}

Funding

This manuscript has been supported by the National Institutes of Health (NIH grant R01 HL130847).

\section{References}

1. Hales CM, Fryar CD, Carroll MD, et al. Trends in Obesity and Severe Obesity Prevalence in US Youth and Adults by Sex and Age, 2007-2008 to 2015-2016. JAMA : the journal of the American Medical Association 20184 24;319(16):1723-1725. doi: 10.1001/jama.2018.3060. [PubMed: 29570750]

2. Beuther DA, Sutherland ER. Overweight, obesity, and incident asthma: a meta-analysis of prospective epidemiologic studies. American journal of respiratory and critical care medicine 2007 4 1;175(7):661-6. doi: 10.1164/rccm.200611-1717OC. [PubMed: 17234901]

3. Guerra S, Sherrill DL, Bobadilla A, et al. The relation of body mass index to asthma, chronic bronchitis, and emphysema. Chest 2002 10;122(4):1256-63. [PubMed: 12377850]

4. Collins LC, Hoberty PD, Walker JF, et al. The effect of body fat distribution on pulmonary function tests. Chest 1995 5;107(5):1298-302. [PubMed: 7750322]

5. Kwon H, Kim D, Kim JS. Body Fat Distribution and the Risk of Incident Metabolic Syndrome: A Longitudinal Cohort Study. Sci Rep 2017 9;7(1):10955. doi: 10.1038/s41598-017-09723-y. [PubMed: 28887474]

6. Pelosi P, Croci M, Ravagnan I, et al. The effects of body mass on lung volumes, respiratory mechanics, and gas exchange during general anesthesia. Anesth Analg 1998 9;87(3):654-60. [PubMed: 9728848]

7. Hedenstierna G, Santesson J. Breathing mechanics, dead space and gas exchange in the extremely obese, breathing spontaneously and during anaesthesia with intermittent positive pressure ventilation. Acta Anaesthesiol Scand 1976;20(3):248-54. [PubMed: 785930]

8. SHARP JT, HENRY JP, SWEANY SK, et al. THE TOTAL WORK OF BREATHING IN NORMAL AND OBESE MEN. J Clin Invest 1964 4;43:728-39. doi: 10.1172/JCI104957. [PubMed: 14149924] 
9. NAIMARK A, CHERNIACK RM. Compliance of the respiratory system and its components in health and obesity. J Appl Physiol 1960 5;15:377-82. [PubMed: 14425845]

10. Schachter LM, Salome CM, Peat JK, et al. Obesity is a risk for asthma and wheeze but not airway hyperresponsiveness. Thorax 2001 1;56(1):4-8. [PubMed: 11120896]

11. Sin DD, Jones RL, Man SF. Obesity is a risk factor for dyspnea but not for airflow obstruction. Arch Intern Med 2002 7;162(13):1477-81. [PubMed: 12090884]

12. Ferretti A, Giampiccolo P, Cavalli A, et al. Expiratory flow limitation and orthopnea in massively obese subjects. Chest 2001 5;119(5):1401-8. [PubMed: 11348945]

13. Sugerman H, Windsor A, Bessos M, et al. Intra-abdominal pressure, sagittal abdominal diameter and obesity comorbidity. J Intern Med 1997 1;241(1):71-9. [PubMed: 9042096]

14. Behazin N, Jones SB, Cohen RI, et al. Respiratory restriction and elevated pleural and esophageal pressures in morbid obesity. J Appl Physiol (1985) 2010 1;108(1):212-8. doi: 10.1152/ japplphysiol.91356.2008. [PubMed: 19910329]

15. Jones RL, Nzekwu MM. The effects of body mass index on lung volumes. Chest 2006 9;130(3): 827-33. doi: 10.1378/chest.130.3.827. [PubMed: 16963682]

16. Sampson MG, Grassino AE. Load compensation in obese patients during quiet tidal breathing. J Appl Physiol Respir Environ Exerc Physiol 1983 10;55(4):1269-76. [PubMed: 6629961]

17. Burki NK, Baker RW. Ventilatory regulation in eucapnic morbid obesity. Am Rev Respir Dis 1984 4;129(4):538-43. [PubMed: 6424520]

18. Chlif M, Keochkerian D, Choquet D, et al. Effects of obesity on breathing pattern, ventilatory neural drive and mechanics. Respir Physiol Neurobiol 2009 9;168(3):198-202. doi: 10.1016/j.resp. 2009.06.012. [PubMed: 19559105]

19. Pelosi P, Croci M, Ravagnan I, et al. Total respiratory system, lung, and chest wall mechanics in sedated-paralyzed postoperative morbidly obese patients. Chest 1996 1;109(1):144-51. [PubMed: 8549177]

20. Tantisira KG, Litonjua AA, Weiss ST, et al. Association of body mass with pulmonary function in the Childhood Asthma Management Program (CAMP). Thorax 2003 12;58(12):1036-41. [PubMed: 14645968]

21. Forno E, Han YY, Mullen J, et al. Overweight, Obesity, and Lung Function in Children and AdultsA Meta-analysis. J Allergy Clin Immunol Pract. 20182018 Mar-Apr;6(2):570-581.e10. doi: 10.1016/j.jaip.2017.07.010.

22. Lazarus R, Colditz G, Berkey CS, et al. Effects of body fat on ventilatory function in children and adolescents: cross-sectional findings from a random population sample of school children. Pediatr Pulmonol 1997 9;24(3):187-94. [PubMed: 9330415]

23. Forno E, Weiner DJ, Mullen J, et al. Obesity and Airway Dysanapsis in Children with and without Asthma. American journal of respiratory and critical care medicine 20172 01;195(3):314-323. doi: 10.1164/rccm.201605-1039OC. [PubMed: 27552676]

24. Ladosky W, Botelho MA, Albuquerque JP. Chest mechanics in morbidly obese non-hypoventilated patients. Respir Med 2001 4;95(4):281-6. doi: 10.1053/rmed.2001.1035. [PubMed: 11316110]

25. Collet F, Mallart A, Bervar JF, et al. Physiologic correlates of dyspnea in patients with morbid obesity. Int J Obes (Lond) 2007 4;31(4):700-6. doi: 10.1038/sj.ijo.0803460. [PubMed: 17006440]

26. Watson RA, Pride NB. Postural changes in lung volumes and respiratory resistance in subjects with obesity. J Appl Physiol 2005 2;98(2):512-7. doi: 00430.2004[pii]10.1152/japplphysiol. 00430.2004. [PubMed: 15475605]

27. Ray CS, Sue DY, Bray G, et al. Effects of obesity on respiratory function. The American review of respiratory disease 1983 9;128(3):501-6. [PubMed: 6614644]

28. Steier J, Lunt A, Hart N, et al. Observational study of the effect of obesity on lung volumes. Thorax 2014 8;69(8):752-9. doi: 10.1136/thoraxjnl-2014-205148. [PubMed: 24736287]

29. Zerah F, Harf A, Perlemuter L, et al. Effects of obesity on respiratory resistance. Chest 1993 5;103(5):1470-6. [PubMed: 8486029]

30. Lazarus R, Sparrow D, Weiss ST. Effects of obesity and fat distribution on ventilatory function: the normative aging study. Chest 1997 4;111(4):891-8. [PubMed: 9106566]

Expert Rev Respir Med. Author manuscript; available in PMC 2019 September 01. 
31. Biring MS, Lewis MI, Liu JT, et al. Pulmonary physiologic changes of morbid obesity. Am J Med Sci 1999 11;318(5):293-7. [PubMed: 10555090]

32. Salome CM, Munoz PA, Berend N, et al. Effect of obesity on breathlessness and airway responsiveness to methacholine in non-asthmatic subjects. Int J Obes (Lond) 2008 3;32(3):502-9. doi: 0803752[pii]10.1038/sj.ijo.0803752. [PubMed: 17955030]

33. Rasslan Z, Junior RS, Stirbulov R, et al. Evaluation of Pulmonary Function in Class I and IIObesity2004 [cited 508-14 p.].

34. Costa D, Barbalho MC, Miguel GP, et al. The impact of obesity on pulmonary function in adult women. Clinics (Sao Paulo) 2008 12;63(6):719-24. [PubMed: 19060990]

35. Leone N, Courbon D, Thomas F, et al. Lung function impairment and metabolic syndrome: the critical role of abdominal obesity. Am J Respir Crit Care Med 2009 3;179(6):509-16. doi: 10.1164/rccm.200807-1195OC. [PubMed: 19136371]

36. Ochs-Balcom HM, Grant BJ, Muti P, et al. Pulmonary function and abdominal adiposity in the general population. Chest 2006 4;129(4):853-62. doi: 10.1378/chest.129.4.853. [PubMed: 16608930]

37. Chapman DG, Berend N, King GG, et al. Increased airway closure is a determinant of airway hyperresponsiveness. Eur Respir J 2008 12;32(6):1563-9. doi: 10.1183/09031936.00114007. [PubMed: 18653648]

38. Pellegrino R, Gobbi A, Antonelli A, et al. Ventilation heterogeneity in obesity. J Appl Physiol (1985) 2014 5;116(9):1175-81. doi: 10.1152/japplphysiol.01339.2013. [PubMed: 24651986]

39. Naoum C, Kritharides L, Ing A, et al. Changes in lung volumes and gas trapping in patients with large hiatal hernia. Clin Respir J 2015 Apr. doi: 10.1111/crj.12314.

40. Chapman DG, Irvin CG, Kaminsky DA, et al. Influence of distinct asthma phenotypes on lung function following weight loss in the obese. Respirology 2014 11;19(8):1170-7. doi: 10.1111/resp. 12368. [PubMed: 25138203]

41. Al-Alwan A, Bates JH, Chapman DG, et al. The nonallergic asthma of obesity. A matter of distal lung compliance. American journal of respiratory and critical care medicine 20146 15;189(12): 1494-502. doi: 10.1164/rccm.201401-01780C. [PubMed: 24821412]

42. Hedenstierna G, Santesson J, Norlander O. Airway closure and distribution of inspired gas in the extremely obese, breathing spontaneously and during anaesthesia with intermittent positive pressure ventilation. Acta Anaesthesiol Scand 1976;20(4):334-42. [PubMed: 793285]

43. Milic-Emili J, Torchio R, D’Angelo E. Closing volume: a reappraisal (1967-2007). Eur J Appl Physiol 2007 4;99(6):567-83. doi: 10.1007/s00421-006-0389-0. [PubMed: 17237952]

44. Hakala K, Mustajoki P, Aittomäki J, et al. Effect of weight loss and body position on pulmonary function and gas exchange abnormalities in morbid obesity. Int J Obes Relat Metab Disord 1995 5;19(5):343-6. [PubMed: 7647827]

45. Mead J, Takishima T, Leith D. Stress distribution in lungs: a model of pulmonary elasticity. J Appl Physiol 1970 5;28(5):596-608. [PubMed: 5442255]

46. Engel LA, Prefaut C. Cranio-caudal distribution of inspired gas and perfusion in supine man. Respir Physiol 1981 7;45(1):43-53. [PubMed: 7280388]

47. Rubinstein I, Zamel N, DuBarry L, et al. Airflow limitation in morbidly obese, nonsmoking men. Ann Intern Med 1990 6;112(11):828-32. [PubMed: 2378649]

48. Ding DJ, Martin JG, Macklem PT. Effects of lung volume on maximal methacholine-induced bronchoconstriction in normal humans. J Appl Physiol 1987 3;62(3):1324-30. [PubMed: 3553143]

49. van Noord JA, Demedts M, Clément J, et al. Effect of rib cage and abdominal restriction on total respiratory resistance and reactance. J Appl Physiol 1986 11;61(5):1736-40. [PubMed: 3781983]

50. Torchio R, Gulotta C, Ciacco C, et al. Effects of chest wall strapping on mechanical response to methacholine in humans. J Appl Physiol (1985) 2006 8;101(2):430-8. doi: 10.1152/japplphysiol. 00379.2005. [PubMed: 16497846]

51. Navajas D, Farre R, Rotger MM, et al. Effect of body posture on respiratory impedance. J Appl Physiol 1988 1;64(1):194-9. [PubMed: 3356637]

52. Litonjua AA, Sparrow D, Celedon JC, et al. Association of body mass index with the development of methacholine airway hyperresponsiveness in men: the Normative Aging Study. Thorax 2002 7;57(7):581-5. [PubMed: 12096199] 
53. Mosen DM, Schatz M, Magid DJ, et al. The relationship between obesity and asthma severity and control in adults. The Journal of allergy and clinical immunology 2008 9;122(3):507-11 e6. doi: 10.1016/j.jaci.2008.06.024. [PubMed: 18774387]

54. Moore WC, Meyers DA, Wenzel SE, et al. Identification of asthma phenotypes using cluster analysis in the Severe Asthma Research Program. Am J Respir Crit Care Med 2010 2;181(4):31523. doi: 10.1164/rccm.200906-08960C. [PubMed: 19892860]

55. Sutherland ER, Goleva E, Strand M, et al. Body mass and glucocorticoid response in asthma. American journal of respiratory and critical care medicine 200810 1;178(7):682-7. doi: 10.1164/ rccm.200801-076OC. [PubMed: 18635892]

56. Dixon A The treatment of asthma in obesity. Expert review of respiratory medicine 20126 ;6(3): 331-40. doi: 10.1586/ers.12.22. [PubMed: 22788947]

57. in 't Veen JC, Beekman AJ, Bel EH, et al. Recurrent exacerbations in severe asthma are associated with enhanced airway closure during stable episodes. Am J Respir Crit Care Med 2000 6;161(6): 1902-6. doi: 10.1164/ajrccm.161.6.9906075. [PubMed: 10852764]

58. Thomas PS, Cowen ER, Hulands G, et al. Respiratory function in the morbidly obese before and after weight loss. Thorax 1989 5;44(5):382-6. [PubMed: 2503905]

59. Lougheed MD, Lam M, Forkert L, et al. Breathlessness during acute bronchoconstriction in asthma. Pathophysiologic mechanisms. Am Rev Respir Dis 1993 12;148(6 Pt 1):1452-9. doi: 10.1164/ajrccm/148.6_Pt_1.1452. [PubMed: 8256884]

60. Holguin F, Bleecker ER, Busse WW, et al. Obesity and asthma: an association modified by age of asthma onset. The Journal of allergy and clinical immunology 2011 6;127(6):1486-93 e2. doi: 10.1016/j.jaci.2011.03.036. [PubMed: 21624618]

61. Shore SA. Obesity, airway hyperresponsiveness, and inflammation. J Appl Physiol (1985) 2010 3;108(3):735-43. doi: 10.1152/japplphysiol.00749.2009. [PubMed: 19875711]

62. Celedon JC, Palmer LJ, Litonjua AA, et al. Body mass index and asthma in adults in families of subjects with asthma in Anqing, China. American journal of respiratory and critical care medicine 200111 15;164(10 Pt 1):1835-40. doi: 10.1164/ajrccm.164.10.2105033. [PubMed: 11734432]

63. Chinn S, Jarvis D, Burney P, et al. Relation of bronchial responsiveness to body mass index in the ECRHS. European Community Respiratory Health Survey. Thorax 2002 12;57(12):1028-33. [PubMed: 12454296]

64. Sood A, Verhulst SJ, Varma A, et al. Association of excess weight and degree of airway responsiveness in asthmatics and non-asthmatics. The Journal of asthma : official journal of the Association for the Care of Asthma 2006 8;43(6):447-52. doi: 10.1080/02770900600758309. [PubMed: 16952863]

65. Bustos P, Amigo H, Oyarzun M, et al. Is there a causal relation between obesity and asthma? Evidence from Chile. International journal of obesity 2005 7;29(7):804-9. doi: 10.1038/sj.ijo. 0802958. [PubMed: 15824747]

66. Fredberg JJ, Inouye DS, Mijailovich SM, et al. Perturbed equilibrium of myosin binding in airway smooth muscle and its implications in bronchospasm. Am J Respir Crit Care Med 1999 3;159(3): 959-67. [PubMed: 10051279]

67. Gunst SJ, Meiss RA, Wu MF, et al. Mechanisms for the mechanical plasticity of tracheal smooth muscle. Am J Physiol 1995 5;268(5 Pt 1):C1267-76. [PubMed: 7762621]

68. Gunst SJ, Wu MF. Selected contribution: plasticity of airway smooth muscle stiffness and extensibility: role of length-adaptive mechanisms. J Appl Physiol (1985) 2001 2;90(2):741-9. [PubMed: 11160077]

69. Seow CY. Myosin filament assembly in an ever-changing myofilament lattice of smooth muscle. Am J Physiol Cell Physiol 2005 12;289(6):C1363-8. doi: 10.1152/ajpcell.00329.2005. [PubMed: 16275736]

70. Trepat X, Deng L, An SS, et al. Universal physical responses to stretch in the living cell. Nature 2007 5;447(7144):592-5. doi: 10.1038/nature05824. [PubMed: 17538621]

71. Krishnan R, Trepat X, Nguyen TT, et al. Airway smooth muscle and bronchospasm: fluctuating, fluidizing, freezing. Respir Physiol Neurobiol 2008 11;163(1-3):17-24. doi: S1569-9048(08)00099-2[pii]10.1016/j.resp.2008.04.006. [PubMed: 18514592] 
72. Fredberg JJ, Inouye D, Miller B, et al. Airway smooth muscle, tidal stretches, and dynamically determined contractile states. Am J Respir Crit Care Med 1997 12;156(6):1752-9. doi: 10.1164/ ajrccm.156.6.9611016. [PubMed: 9412551]

73. Salome CM, Thorpe CW, Diba C, et al. Airway re-narrowing following deep inspiration in asthmatic and nonasthmatic subjects. Eur Respir J 2003 7;22(1):62-8. [PubMed: 12882452]

74. Golnabi AH, Harris RS, Venegas JG, et al. Deep inspiration and the emergence of ventilation defects during bronchoconstriction: a computational study. PLoS One 2014;9(11):e112443. doi: 10.1371/journal.pone.0112443. [PubMed: 25402457]

75. Castro-Rodríguez JA, Holberg CJ, Morgan WJ, et al. Increased incidence of asthmalike symptoms in girls who become overweight or obese during the school years. Am J Respir Crit Care Med 2001 5;163(6):1344-9. doi: 10.1164/ajrccm.163.6.2006140. [PubMed: 11371399]

76. Dixon AE, Shade DM, Cohen RI, et al. Effect of obesity on clinical presentation and response to treatment in asthma. J Asthma 2006 9;43(7):553-8. doi: 10.1080/02770900600859123. [PubMed: 16939998]

77. Peters U, Hernandez P, Dechman G, et al. Early detection of changes in lung mechanics with oscillometry following bariatric surgery in severe obesity. Appl Physiol Nutr Metab 2016 1;41(5): 538-47. doi: 10.1139/apnm-2015-0473. [PubMed: 27109263]

78. Holley HS, Milic-Emili J, Becklake MR, et al. Regional distribution of pulmonary ventilation and perfusion in obesity. J Clin Invest 1967 4;46(4):475-81. doi: 10.1172/JCI105549. [PubMed: 6021200]

79. Rivas E, Arismendi E, Agustí A, et al. Ventilation/Perfusion distribution abnormalities in morbidly obese subjects before and after bariatric surgery. Chest 2015 4;147(4):1127-1134. doi: 10.1378/ chest.14-1749. [PubMed: 25317652]

80. Enache I, Oswald-Mammosser M, Scarfone S, et al. Impact of altered alveolar volume on the diffusing capacity of the lung for carbon monoxide in obesity. Respiration 2011;81(3):217-22. doi: 10.1159/000314585. [PubMed: 20453485]

81. Hakala K, Stenius-Aarniala B, Sovijärvi A. Effects of weight loss on peak flow variability, airways obstruction, and lung volumes in obese patients with asthma. Chest 2000 11;118(5):1315-21. [PubMed: 11083680]

82. Aaron SD, Fergusson D, Dent R, et al. Effect of weight reduction on respiratory function and airway reactivity in obese women. Chest 2004 6;125(6):2046-52. [PubMed: 15189920]

83. Pakhale S, Baron J, Dent R, et al. Effects of weight loss on airway responsiveness in obese adults with asthma: does weight loss lead to reversibility of asthma? Chest 2015 6;147(6):1582-90. doi: 10.1378/chest.14-3105. [PubMed: 25763936]

84. Womack CJ, Harris DL, Katzel LI, et al. Weight loss, not aerobic exercise, improves pulmonary function in older obese men. J Gerontol A Biol Sci Med Sci 2000 8;55(8):M453-7. [PubMed: 10952368]

85. Dixon AE, Pratley RE, Forgione PM, et al. Effects of obesity and bariatric surgery on airway hyperresponsiveness, asthma control, and inflammation. The Journal of allergy and clinical immunology 2011 9;128(3):508-15 e1-2. doi: 10.1016/j.jaci.2011.06.009. [PubMed: 21782230]

86. Weisberg SP, McCann D, Desai M, et al. Obesity is associated with macrophage accumulation in adipose tissue. J Clin Invest 2003 12;112(12):1796-808. doi: 10.1172/JCI19246. [PubMed: 14679176]

87. Sideleva O, Suratt BT, Black KE, et al. Obesity and asthma: an inflammatory disease of adipose tissue not the airway. American journal of respiratory and critical care medicine 201210 1;186(7): 598-605. doi: 10.1164/rccm.201203-05730C. [PubMed: 22837379]

88. Periyalil HA, Wood LG, Wright TA, et al. Obese asthmatics are characterized by altered adipose tissue macrophage activation. Clinical and experimental allergy : journal of the British Society for Allergy and Clinical Immunology 2018 131. doi: 10.1111/cea.13109.

89. Poglio S, De Toni-Costes F, Arnaud E, et al. Adipose tissue as a dedicated reservoir of functional mast cell progenitors. Stem Cells 2010 11;28(11):2065-72. doi: 10.1002/stem.523. [PubMed: 20845475]

Expert Rev Respir Med. Author manuscript; available in PMC 2019 September 01. 
90. Liu J, Divoux A, Sun J, et al. Genetic deficiency and pharmacological stabilization of mast cells reduce diet-induced obesity and diabetes in mice. Nat Med 2009 8;15(8):940-5. doi: 10.1038/nm. 1994. [PubMed: 19633655]

91. Polotsky VY, Smaldone MC, Scharf MT, et al. Impact of interrupted leptin pathways on ventilatory control. J Appl Physiol (1985) 2004 3;96(3):991-8. doi: 10.1152/japplphysiol.00926.2003. [PubMed: 14578371]

92. Bassi M, Furuya WI, Menani JV, et al. Leptin into the ventrolateral medulla facilitates chemorespiratory response in leptin-deficient (ob/ob) mice. Acta Physiol (Oxf) 2014 5;211(1): 240-8. doi: 10.1111/apha.12257. [PubMed: 24521430]

93. Torday JS, Powell FL, Farmer CG, et al. Leptin integrates vertebrate evolution: from oxygen to the blood-gas barrier. Respir Physiol Neurobiol 20108 31;173 Suppl:S37-42. doi: 10.1016/j.resp. 2010.01.007. [PubMed: 20096383]

94. De Blasio MJ, Boije M, Kempster SL, et al. Leptin Matures Aspects of Lung Structure and Function in the Ovine Fetus. Endocrinology 2016 1;157(1):395-404. doi: 10.1210/en.2015-1729. [PubMed: 26479186]

95. Hickson DA, Burchfiel CM, Petrini MF, et al. Leptin is inversely associated with lung function in African Americans, independent of adiposity: the Jackson Heart Study. Obesity (Silver Spring) 2011 5;19(5):1054-61. doi: 10.1038/oby.2010.240. [PubMed: 20966906]

96. Sood A, Ford ES, Camargo CA. Association between leptin and asthma in adults. Thorax 2006 4;61(4):300-5. doi: 10.1136/thx.2004.031468. [PubMed: 16540481]

97. Bulló M, Garcia-Lorda P, Salas-Salvadó J. Plasma soluble tumor necrosis factor alpha receptors and leptin levels in normal-weight and obese women: effect of adiposity and diabetes. Eur $\mathbf{J}$ Endocrinol 2002 3;146(3):325-31. [PubMed: 11888838]

98. Bulló M, García-Lorda P, Megias I, et al. Systemic inflammation, adipose tissue tumor necrosis factor, and leptin expression. Obes Res 2003 4;11(4):525-31. doi: 10.1038/oby.2003.74. [PubMed: 12690081]

99. Bastard JP, Jardel C, Bruckert E, et al. Elevated levels of interleukin 6 are reduced in serum and subcutaneous adipose tissue of obese women after weight loss. J Clin Endocrinol Metab 2000 9;85(9):3338-42. doi: 10.1210/jcem.85.9.6839. [PubMed: 10999830]

100. Roth CL, Kratz M, Ralston MM, et al. Changes in adipose-derived inflammatory cytokines and chemokines after successful lifestyle intervention in obese children. Metabolism 2011 4;60(4): 445-52. doi: 10.1016/j.metabol.2010.03.023. [PubMed: 20494373]

101. Zaldivar F, McMurray RG, Nemet D, et al. Body fat and circulating leukocytes in children. Int J Obes (Lond) 2006 6;30(6):906-11. doi: 10.1038/sj.ijo.0803227. [PubMed: 16418751]

102. van Veen IH, Ten Brinke A, Sterk PJ, et al. Airway inflammation in obese and nonobese patients with difficult-to-treat asthma. Allergy 2008 5;63(5):570-4. doi: 10.1111/j. 1398-9995.2007.01597.x. [PubMed: 18394131]

103. Desai D, Newby C, Symon FA, et al. Elevated sputum interleukin-5 and submucosal eosinophilia in obese individuals with severe asthma. American journal of respiratory and critical care medicine 20139 15;188(6):657-63. doi: 10.1164/rccm.201208-1470OC. [PubMed: 23590263]

104. Scott HA, Gibson PG, Garg ML, et al. Airway inflammation is augmented by obesity and fatty acids in asthma. Eur Respir J 2011 9;38(3):594-602. doi: 10.1183/09031936.00139810. [PubMed: 21310876]

105. Johnston RA, Theman TA, Shore SA. Augmented responses to ozone in obese carboxypeptidase E-deficient mice. Am J Physiol Regul Integr Comp Physiol 2006 1;290(1):R126-33. doi: 10.1152/ajpregu.00306.2005. [PubMed: 16002559]

106. Shore SA, Rivera-Sanchez YM, Schwartzman IN, et al. Responses to ozone are increased in obese mice. J Appl Physiol (1985) 2003 9;95(3):938-45. doi: 10.1152/japplphysiol.00336.2003. [PubMed: 12794034]

107. Chiumello D, Colombo A, Algieri I, et al. Effect of body mass index in acute respiratory distress syndrome. BJA: British Journal of Anaesthesia 2016;116(1):113-121. doi: 10.1093/bja/aev378. [PubMed: 26675954]

Expert Rev Respir Med. Author manuscript; available in PMC 2019 September 01. 
108. Bime C, Fiero M, Lu Z, et al. High Positive End-Expiratory Pressure Is Associated with Improved Survival in Obese Patients with Acute Respiratory Distress Syndrome. Am J Med 2017 2;130(2): 207-213. doi: 10.1016/j.amjmed.2016.09.029. [PubMed: 27984004]

109. Kenchaiah S, Evans JC, Levy D, et al. Obesity and the risk of heart failure. N Engl J Med 2002 8;347(5):305-13. doi: 10.1056/NEJMoa020245. [PubMed: 12151467]

110. L. F, C. J, A. H, et al. Obesity is associated with higher risk of intensive care unit admission and death in influenza A (H1N1) patients: a systematic review and meta-analysis. Obesity Reviews 2011;12(8):653-659. doi: doi:10.1111/j.1467-789X.2011.00864.x. [PubMed: 21457180]

111. Ubags ND, Stapleton RD, Vernooy JH, et al. Hyperleptinemia is associated with impaired pulmonary host defense. JCI Insight 2016 6;1(8). doi: 10.1172/jci.insight.82101.

112. Zhi G, Xin W, Ying W, et al. "Obesity Paradox" in Acute Respiratory Distress Syndrome: Asystematic Review and Meta-Analysis. PLoS One. 2016 2016;11(9):e0163677. doi: 10.1371/ journal.pone.0163677.

113. Shah D, Romero F, Duong M, et al. Obesity-induced adipokine imbalance impairs mouse pulmonary vascular endothelial function and primes the lung for injury. Sci Rep 2015 6;5:11362. doi: 10.1038/srep11362. [PubMed: 26068229]

114. Ubags ND, Burg E, Antkowiak M, et al. A Comparative Study of Lung Host Defense in Murine Obesity Models. Insights into Neutrophil Function. Am J Respir Cell Mol Biol 2016 08;55(2): 188-200. doi: 10.1165/rcmb.2016-0042OC. [PubMed: 27128821]

115. Agrawal A, Mabalirajan U, Ahmad T, et al. Emerging interface between metabolic syndrome and asthma. Am J Respir Cell Mol Biol 2011 3;44(3):270-5. doi: 10.1165/rcmb.2010-0141TR. [PubMed: 20656947]

116. Dekkers BG, Schaafsma D, Tran T, et al. Insulin-induced laminin expression promotes a hypercontractile airway smooth muscle phenotype. Am J Respir Cell Mol Biol 2009 10;41(4): 494-504. doi: 10.1165/rcmb.2008-0251OC. [PubMed: 19213874]

117. Forno E, Han Y-Y, Muzumdar RH, et al. Insulin resistance, metabolic syndrome, and lung function in US adolescents with and without asthma. Journal of Allergy and Clinical Immunology 2015 2015/08/01/;136(2):304-311.e8. doi: 10.1016/j.jaci.2015.01.010. [PubMed: 25748066]

118. Nakajima K, Kubouchi Y, Muneyuki T, et al. A Possible Association Between Suspected Restrictive Pattern as Assessed by Ordinary Pulmonary Function Test and the Metabolic Syndrome. Chest 2008 2008/10/01/;134(4):712-718. doi: 10.1378/chest.07-3003. [PubMed: 18625672]

119. Brumpton BM, Camargo CA, Romundstad PR, et al. Metabolic syndrome and incidence of asthma in adults: the HUNT study. Eur Respir J 2013 12;42(6):1495-502. doi: 10.1183/09031936.00046013. [PubMed: 23845717]

120. Zaigham S, Nilsson PM, Wollmer P, et al. The temporal relationship between poor lung function and the risk of diabetes. BMC Pulm Med 2016 5;16(1):75. doi: 10.1186/s12890-016-0227-z. [PubMed: 27165091]

121. Brittain EL, Nwabuo C, Xu M, et al. Echocardiographic Pulmonary Artery Systolic Pressure in the Coronary Artery Risk Development in Young Adults (CARDIA) Study: Associations With Race and Metabolic Dysregulation. J Am Heart Assoc 2017 3;6(4). doi: 10.1161/JAHA. 116.005111.

122. Meng Q, Lai YC, Kelly NJ, et al. Development of a Mouse Model of Metabolic Syndrome, Pulmonary Hypertension, and Heart Failure with Preserved Ejection Fraction. Am J Respir Cell Mol Biol 2017 04;56(4):497-505. doi: 10.1165/rcmb.2016-0177OC. [PubMed: 28118022]

123. Lavie M, Fisher D, Vilozni D, et al. Glucose intolerance in cystic fibrosis as a determinant of pulmonary function and clinical status. Diabetes Research and Clinical Practice 2015 2015/12/01/;110(3):276-284. doi: 10.1016/j.diabres.2015.10.007. [PubMed: 26508676]

124. Ford ES, Cunningham TJ, Mercado CI. Lung function and metabolic syndrome: Findings of National Health and Nutrition Examination Survey 2007-2010. J Diabetes 2014 11;6(6):603-13. [PubMed: 26677470] 
125. Scarlata S, Fimognari FL, Cesari M, et al. Lung function changes in older people with metabolic syndrome and diabetes. Geriatr Gerontol Int 2013 10;13(4):894-900. doi: 10.1111/ggi.12026. [PubMed: 23311827]

126. Fimognari FL, Pasqualetti P, Moro L, et al. The association between metabolic syndrome and restrictive ventilatory dysfunction in older persons. J Gerontol A Biol Sci Med Sci 2007 7;62(7): 760-5. [PubMed: 17634324]

127. Griffith KA, Sherrill DL, Siegel EM, et al. Predictors of loss of lung function in the elderly: the Cardiovascular Health Study. Am J Respir Crit Care Med 2001 1;163(1):61-8. doi: 10.1164/ ajrccm.163.1.9906089. [PubMed: 11208627]

128. Enright PL, Kronmal RA, Manolio TA, et al. Respiratory muscle strength in the elderly. Correlates and reference values. Cardiovascular Health Study Research Group. Am J Respir Crit Care Med 1994 2;149(2 Pt 1):430-8. doi: 10.1164/ajrccm.149.2.8306041. [PubMed: 8306041]

129. Landbo C, Prescott E, Lange P, et al. Prognostic value of nutritional status in chronic obstructive pulmonary disease. Am J Respir Crit Care Med 1999 12;160(6):1856-61. doi: 10.1164/ajrccm. 160.6.9902115. [PubMed: 10588597]

130. Mittman C, Edelman NH, Norris AH, et al. Relationship between chest wall and pulmonary compliance and age. Journal of Applied Physiology 1965;20(6):1211-1216. doi: 10.1152/jappl. 1965.20.6.1211.

131. Petrella F, Radice D, Borri A, et al. The impact of preoperative body mass index on respiratory complications after pneumonectomy for non-small-cell lung cancer. Results from a series of 154 consecutive standard pneumonectomies. Eur J Cardiothorac Surg 2011 5;39(5):738-44. doi: 10.1016/j.ejcts.2010.09.007. [PubMed: 20952203]

132. Eichenberger A, Proietti S, Wicky S, et al. Morbid obesity and postoperative pulmonary atelectasis: an underestimated problem. Anesth Analg 2002 12;95(6):1788-92, table of contents. [PubMed: 12456460]

133. Lohser J, Kulkarni V, Brodsky JB. Anesthesia for thoracic surgery in morbidly obese patients. Curr Opin Anaesthesiol 2007 2;20(1):10-4. doi: 10.1097/ACO.0b013e32800ff73c. [PubMed: 17211160] 


\section{Key Issues}

- Obesity has a major impact on respiratory function, and contributes significantly to the development of lung disease

- $\quad$ BMI has limited utility in understanding the effect of obesity on the lung: differing distributions of adipose tissue will differentially affect mechanics and are associated with different levels of metabolic dysfunction, and so understanding the distribution of adipose tissue is important to estimate both the mechanical and metabolic effects of obesity on lung function.

- Obesity and diseases such as asthma are diseases with many phenotypes: accurate assessment of the phenotype of both the lung disease and the obesity is needed to understand the effects of obesity on lung disease.

- Time of onset of obesity is likely important in the effects on lung function: obese children develop accelerated lung growth, with FVC increasing more than FEV1 and airway dysynapsis, how this effects disease later in life is not clear.

- Obesity increases airway closure, which may exacerbate airway reactivity, affect delivery of inhaled medications, and predispose to more severe derangement during exacerbations.

- Obesity alters the distribution of ventilation towards the upper lobes, which likely contributes to ventilation inhomogeneity and the burden of respiratory disease.

- Conventional pulmonary function testing likely underestimates the effects of obesity on respiratory function, as deep breath maneuvers likely reverse the effects of breathing at low FRC in obesity, and ventilation-perfusion relationships are not measured. 


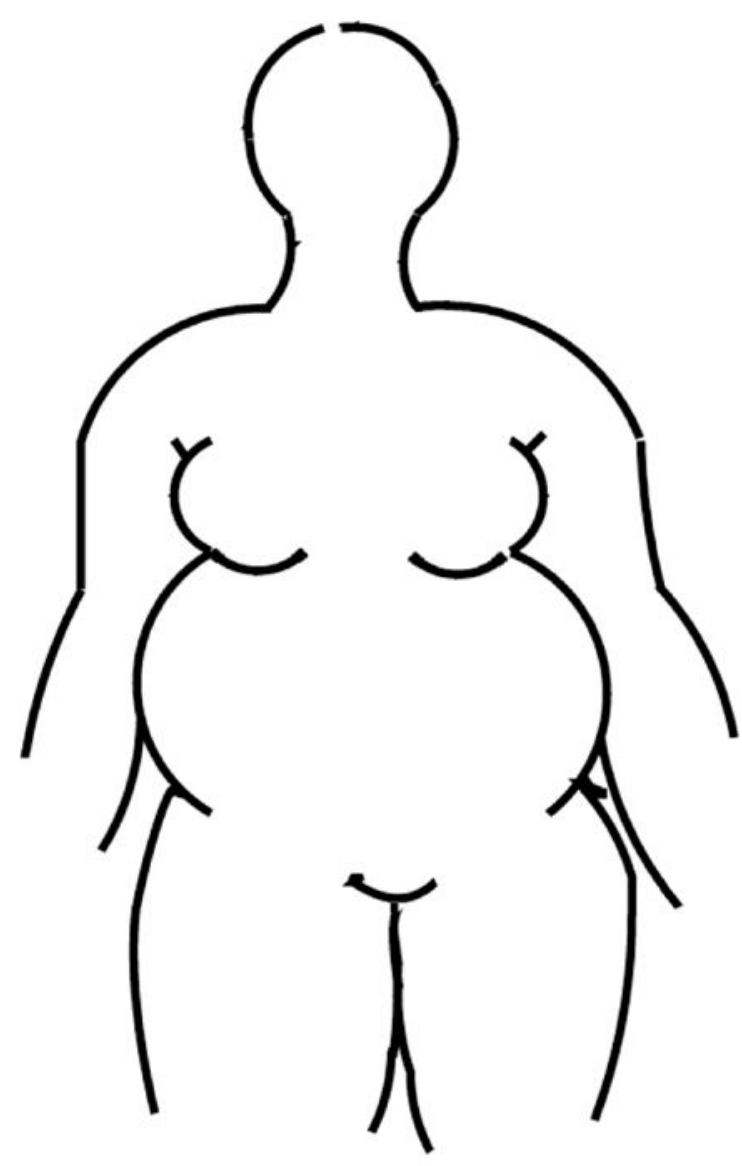

Android Obesity

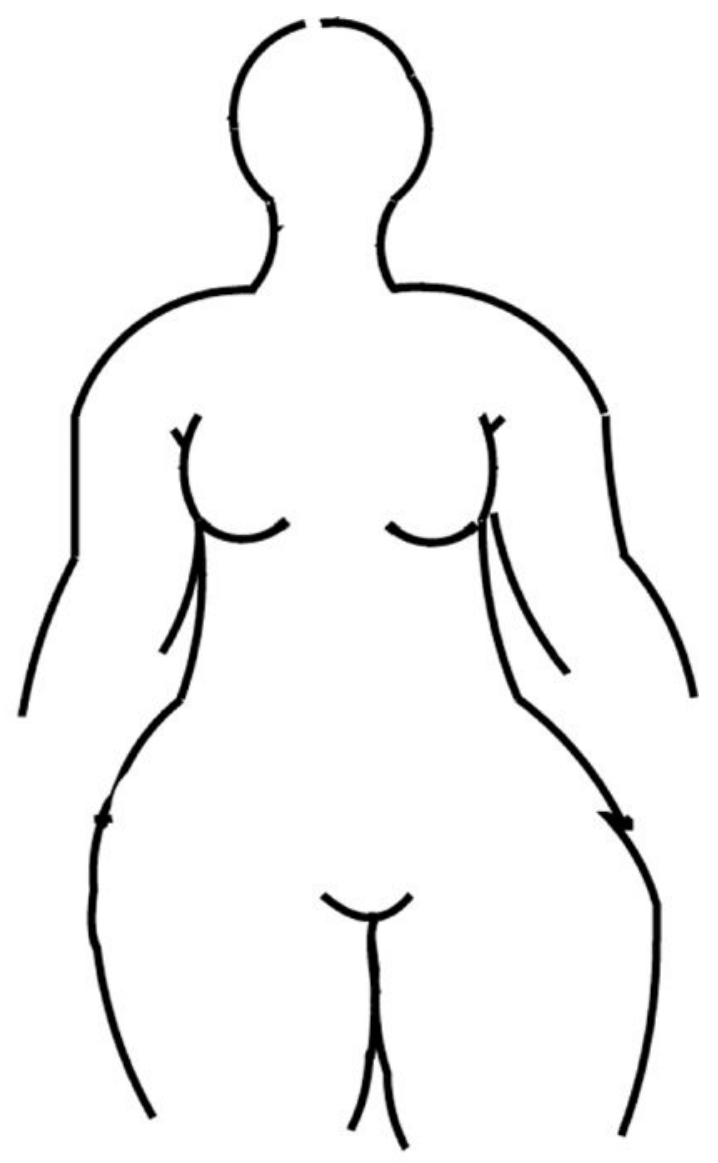

Gynoid Obesity

Figure 1.

Typical patterns of regional fat distribution in overweight and obese patients. 


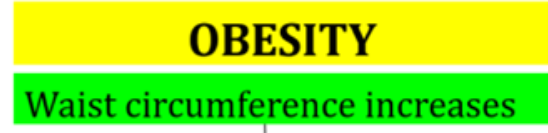

Lung compression

FRC reduces

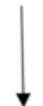

Attenuation of tethering forces between the airway and parenchyma

\begin{tabular}{|c|c|}
\hline $\begin{array}{c}\text { Substantial } \\
\text { narrowing and } \\
\text { collapse of } \\
\text { central airways }\end{array}$ & $\begin{array}{l}\text { Alveolar } \\
\text { derecruitment } \\
\text { and collapse of } \\
\text { small airways }\end{array}$ \\
\hline Rrs increases & Xrs decreases \\
\hline
\end{tabular}

Figure 2.

Summary of findings recorded in obese patients at baseline and after weight loss. See text for likely mechanisms for these findings. 


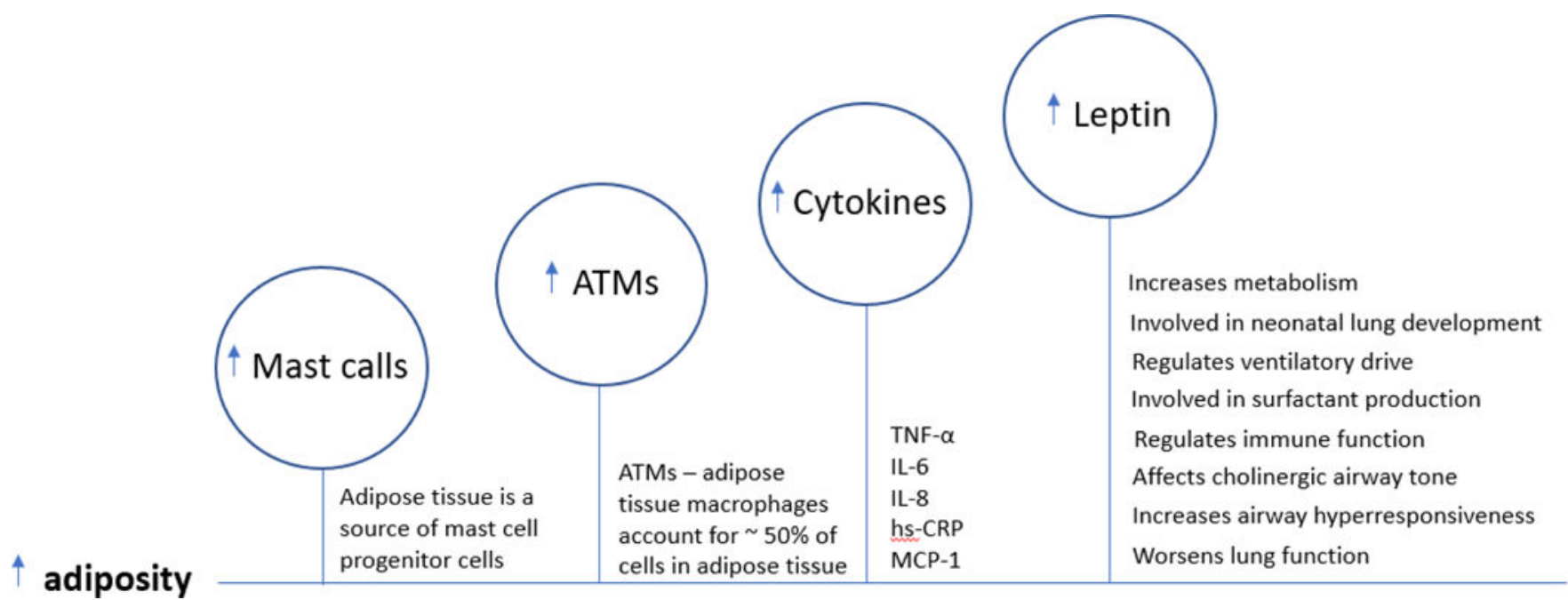

Figure 3.

Immune cells and adipokines increased in obesity and their effect on lung function 
Table 1.

Key studies on the mechanics of the lungs, chest wall and total respiratory system in obesity

\begin{tabular}{|c|c|c|}
\hline Author & Year & Main findings \\
\hline Pelosi et al [6] & 1998 & $\begin{array}{l}\text { FRC, lung compliance, and Crs decreased exponentially with increasing BMI, whereas the compliance of the } \\
\text { chest wall was only minimally affected. Lung resistance and Rrs also increased with BMI, but chest wall } \\
\text { resistance was unaffected. }\end{array}$ \\
\hline Hedenstierna et al [7] & 1976 & $\begin{array}{l}\text { Lung compliance decreased significantly in extremely obese subjects while lung resistance was elevated but } \\
\text { chest wall compliance was WNL. Moderate hypoxemia was recorded during artificial ventilation. }\end{array}$ \\
\hline Sharp et al [8] & 1964 & $\begin{array}{l}\text { The authors found significant differences in lung, thoracic and total compliances between normal subjects, } \\
\text { obese normal subjects and patients with OHS. }\end{array}$ \\
\hline Behazin et al [14] & 2010 & $\begin{array}{l}\text { Esophageal pressure was higher in obese than control subjects. Crs was lower in the obese group and this was } \\
\text { attributed to lower lung compliance rather than to chest wall compliance. }\end{array}$ \\
\hline Jones et al [15] & 2006 & $\begin{array}{l}\text { FRC and ERV decreased exponentially with increasing BMI and the reduction was proportional to the severity } \\
\text { of obesity. Overweight, mildly obese and severely obese subjects demonstrate reductions in FRC of up to } 10 \% \text {, } \\
22 \% \text { and } 33 \% \text {, respectively. }\end{array}$ \\
\hline Sampson et al [16] & 1983 & $\begin{array}{l}\text { The volume-generating function of the diaphragm was reduced in obesity and this resulted in slightly lower } \\
\text { tidal volume in obese patients as compared to normal subjects. }\end{array}$ \\
\hline Burki et al [17] & 1984 & $\begin{array}{l}\text { TLC, FRC and Crs were significantly lower in patients with obesity; however, an increase in mean respiratory } \\
\text { rate was recorded, such that the overall minute ventilation at rest was significantly elevated. }\end{array}$ \\
\hline Steier et al [28] & 2014 & $\begin{array}{l}\text { This study demonstrated that esophageal and gastric pressure measured in the seated position at FRC were } \\
\text { significantly elevated in obese subjects as compared to their healthy counterparts who were matched for age, } \\
\text { gender and height. BMI correlated with gastric and esophageal pressures. }\end{array}$ \\
\hline
\end{tabular}

FRC, functional residual capacity; Crs, compliance of total respiratory system; Rrs, resistance of total respiratory system; WNL, within normal limits; OHS, obesity hypoventilation syndrome; TLC, total lung capacity; ERV, expiratory reserve volume; BMI, body mass index. 